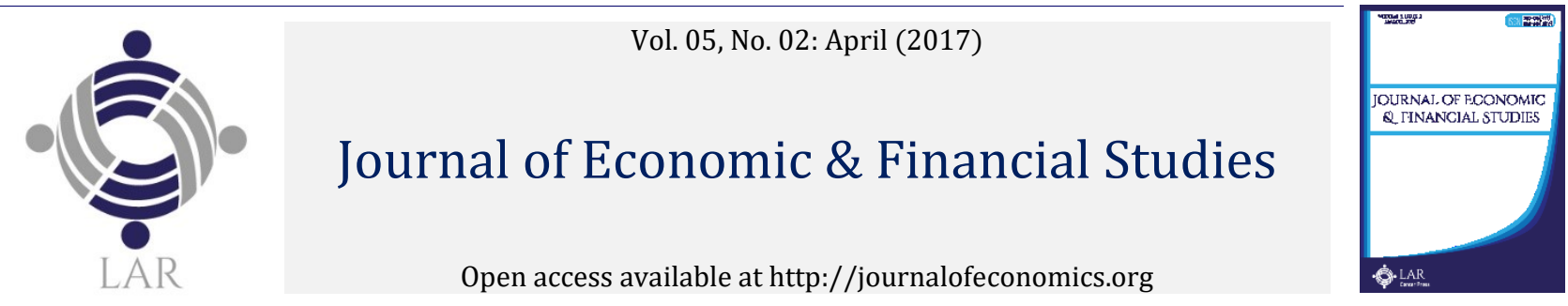

\title{
Initial public offering (IPO) underpricing in Malaysian settings
}

\author{
Edward Wong Sek Khin a*, Ricky Wong W Ba, Lee Sue Tinga \\ a Faculty of Business and Accountancy, University of Malaya, Kuala Lumpur, Malaysia. \\ *Corresponding author's email address: sek188@yahoo.com
}

\section{A R T I C LE IN F O}

Received: 23-02-2017

Accepted: 03-04-2017

Available online: $13-04-2017$

Keywords:

Emergent Market;

Market Efficiency;

Stock Market Volatility.

\begin{abstract}
A B S T R A C T
Empirical debate on Initial public offering (IPO) underpricing has never laid to rest. Motivated by the IPO underpricing phenomenon across various market, this paper examines the anomalous market behaviors of IPO in an emerging market setting such as Malaysia. The primary purpose of this paper is to analyze the existence and magnitude of the underpricing phenomenon and post listing performance of IPOs listed in Bursa Malaysia from 2008 to 2016. Moreover, this study aims to provide an insight primarily into the relationship between IPO initial and long-term stock performance and the four main determinants influencing underpricing, namely IPO size, market volatility, underwriter status and the reciprocal of IPO price. By analyzing a sample of 313 IPOs, the average market adjusted initial return is $9.4 \%$. The regression-based analysis indicates positive relationship between underpricing and the explanatory variables, namely IPO size, market volatility, underwriter status and the reciprocal of IPO price. In addition, the findings of the present study lend support to the evidence of a fads hypothesis as the sample IPO was found to underperform the market over a 36month period after listing and a univariate regression analysis further reveals that there is a negative relationship between initial market adjusted returns and returns over the 36-month period.
\end{abstract}

JEL Classification :

G24; G32: G38.

(C) 2017 The Authors. This is an open access article under the terms of the Creative Commons Attribution License 4.0, which allows use, distribution and reproduction in any medium, provided the original work is properly cited.

DOI: http://dx.doi.org/10.18533/jefs.v5i02.276

\section{Introduction}

Initial Public Offerings (IPOs) underpricing, i.e., a positive gain of new stock on a listing day compared to its IPO offer price is a common phenomenon in many markets. The dominance of positive first day returns for IPOs has puzzled finance academics for decades. A large body of finance literature has proposed various models and hypotheses to explain this so-called underpricing phenomenon. In other words, on average, an investor who subscribes new IPO issues at the offer price and sells them at the closing price on the first day can make positive returns. The investigation of IPO pricing and performance is one of those market anomalies that continuously attracts the attention of many researchers in finance.

Several theories have been put forward to argue that underpricing of IPO is an equilibrium occurrence in an efficient capital market. In fact, to some degree, deliberate IPO underpricing by the issuers and underwriters is needed for different reasons. It is understandable that if the IPO subscription price is set at a lower valuation than the expected valuation of new shares, then IPO subscribers would be able to earn a positive rate of initial return on the first trading day upon listing.

The short-run and long-run performances of IPOs are the most frequently research topics of IPO studies which give rise to a vast body of empirical research concerning the two most important anomalies of IPOs. Two well- 
known findings have been the focus of substantial theoretical and empirical studies in the IPO literature for many years. Firstly, it is the presence of underpricing in IPOs. Investors who subscribe for IPO shares and sell them during the first day of trading earn a positive return where the closing price on the first day of trading is higher than the offering price. Secondly, new stocks generally decline or underperform the market for three to five years following the offering date. Investors who buy IPO shares at the end of the first trading day will earn a long-run return far less than that of comparable stocks. These two persistent anomalous behaviors that characterize IPOs, that is, the first-day underpricing and the long-term underperformance of certain IPOs, have intrigued academics and scholars over the past two decades and have generated considerable research to provide explanations and reasons behind this phenomenon.

This anomalous behavior is observed in many countries. Ritter $(1984,1991)$, has confirmed the existence of IPO underpricing in the United States. This is surprising when it is a fact that underpricing can be very costly to company shareholders, in that the 'money left on the table' amounts to billions of dollars. From the 1960s onwards, the price discount has averaged around 19\%. However, the price discount fluctuated considerably, achieving an average of $21 \%$ in the 1960 s, $12 \%$ in the 1970 s, $16 \%$ in the 1980 s, $21 \%$ in the 1990 s and $40 \%$ in the 4 years since 2000 (Ljungqvist, 2005). The level of underpricing was even more evident in the late 1990s and in the beginning years since 2000, where market sentiment was bullish with the Internet IPO boom.

This study is exploratory in nature and investigates whether there is an existence of underpricing for IPOs listed on the Kuala Lumpur (KL) Bursa Main Board or KLSE from the year 2008 to 2016. Although there is a large amount of research that investigates these issues in most developed country's stock markets, only a few studies have been undertaken in the developing Malaysian context, particularly in the aftermath of the Asian financial crisis that gripped much of the Asian region in 1997. Hence, this paper aims to examine the initial and long-run performance of IPOs listed in the KL Bursa from the period 1 January 2008 to 31 December 2016.

The aim of this research paper is to provide an empirical review of short run and long-run performance of IPOs by addressing the questions: (a) re-examining the evidence IPO underpricing in Malaysian context; (b) analyze the initial and short-run and long-run performance of IPOs; (c) investigate the possible determinants for IPO underpricing.

The rest of the paper follows the followings. Section 2 presents the literature review. Section 3 presents the research methodology. Section 4 presents the Empirical findings and results. Section 5 presents the discussion of the results. Section 6 concludes the paper.

\section{Literature review}

\subsection{The short run underpricing of IPOs}

Most companies that go public do so via an initial public offering (IPO) of shares to investors. The issue of underpricing in IPO has been an extensive field for investigation in the financial community, especially during the last decade. This underpricing phenomenon has garnered enormous interest among the financial economists for many decades. In the early days, some studies focus on some specific factors in explaining the underpricing phenomenon. Early researchers such as Logue (1973) and Ibbotson (1975), documented that when companies go public, the IPO shares tend to be underpriced, in that the share price jumps on the first day of trading. This means that an investor who purchases new issues at the offering price and sells them at the closing price on the first day of listing is able, on average, to make a relatively large return.

Using the data from 1990 till 1998, Loughran and Ritter (2000) found that initial returns on IPOs averaged about 15 percent which was equivalent to approximately USD27 billion of potential IPO proceeds that were 'left on the table' because of underpricing. More recently, another observation by Ritter (2001) documented that during the two-year period from 1999 to 2000, about USD65 billion was 'left on the table' from the IPOs raised.

Jelic, Saadouni and Briston (2001) using 182 IPOs on the KLSE Main Board over the period January 1980 to December 1995 documented that the degree of underpricing appeared to be exceptionally evident during the 'hot issue' periods of 1983-1985 and 1993-1995. Koh and Walter (1989) using 66 IPOs in Singapore Stock Exchange during 1973 to 1987 reveal similarities with the main conclusions of Rock's (1986) model i.e. there is a significant positive correlation between the oversubscription level and first day returns. In Singapore, if the IPOs are oversubscribed, all subscribers of a particular size have an equal chance to purchase shares. This allocation process makes the calculation of the probabilities of obtaining an allocation conform to Rock's model. Furthermore, they also found that underpricing is more prevalent among large investors than small ones. 
Levis (1990) demonstrates that the underpricing of IPOs can be accounted for by the "winner's curse" problem and interest rate cost in his studies on 123 IPOs in London Stock Exchange from the period January 1985 to December 1988. After the allocation rate and interest rate cost are considered, the first-day return is not significantly different from zero. Keloharju (1993) studies 80 IPOs in the Finnish market from 1984 to 1989. His evidence confirms the existence of the "winner's curse" where there is a significantly negative relation between allocation rate and first-day return.

The degree of underpricing varies considerably across markets. Loughran et al. (1994) provides an international survey of IPO performance in 25 countries, including 7 regional countries with an average initial return of $78.1 \%$ for Korea; $32.5 \%$ for Japan; $17.6 \%$ for Hong Kong; $80.3 \%$ for Malaysia; $27.0 \%$ for Singapore; $58.1 \%$ for Thailand and $45.0 \%$ for Taiwan. From their investigation, they conclude that the move by East Asian economies to reduce regulatory intervention in fixing IPO subscription prices should result in less underpricing of IPOs in the 1990s compared to the 1980 s.

Ritter (2003) reports that the average initial returns experienced in Asian IPOs are significantly higher than the mean initial returns of U.S. IPOs. For example, his research shows that the mean initial return of new listings in 33 countries ranged from $13.6 \%$ to $388 \%$ in the developing market and $4.2 \%$ to $54.4 \%$ in developed markets. In addition, he also reports the extent of underpricing in these countries, including 11 Asian countries with an average initial return of $256.9 \%$ for China, $31.4 \%$ for Singapore, $74.3 \%$ for Korea, $35.3 \%$ for India, $15.9 \%$ for Hong Kong, $15.1 \%$ for Indonesia, 28.4\% for Japan, $104.1 \%$ for Malaysia, $22.7 \%$ for the Philippines, $31.1 \%$ for Taiwan, and $46.7 \%$ for Thailand. Beatty and Ritter (1986) relate the level of ex-ante uncertainty surrounding the intrinsic value of an IPO to the level of underpricing; the higher the uncertainty level, the higher is the level of underpricing.

\subsection{Long-run underperformance of IPOs}

One puzzle in the IPO literature is why the value of IPO investments generally decline after going public. Previous findings on long-run performance indicate the significantly poor long-term performance of IPOs. In other words, IPO investors who buy shares at the end of the first trading day tend to earn a three-year cumulative return far less than that of comparable stocks. Ritter (1991) was among the first to document poor abnormal returns following an IPO. Ritter (1991) and Loughran and Ritter (1995) have documented that in the long-run, the U.S. IPOs are overpriced. Ritter (1991) and Loughran and Ritter (1995) advocate that the long-run underperformance of IPOs was attributable to the overreactions or over-excitement by investors at the IPO offering dates, leading to the high initial returns. They also argue that companies can intentionally time their offerings for periods when the market sentiment is positive and where investors are over-optimistic.

The long-run performance of IPOs has been confirmed in many countries (Loughran, Ritter, and Rydqvist, 1994). In addition, most subsequent research, using larger and longer sample periods in the US market and overseas, confirmed Ritter's initial results. The growing bodies of empirical literature on IPOs provide evidence of positive short-term returns but long-term losses. Some notable literature examples are Ritter (1991) for the US, Keloharju (1993) for Finland, Uhlir (1989) for Germany, Levis (1993) for the UK, Aggarwal, et al. (1993) for Brazil, Chile, and Mexico.

Ritter (1991) studies the IPOs in the US during the years from 1975 to 1984. His findings reveal that new issues substantially underperformed a sample of matching firms from the closing price on the first day of public trading to their 3 year's anniversaries. The average return for a three-year holding period return for the sample after going public was about $34.47 \%$ whereas a control sample of 1,526 listed stocks matched by market value and industry was found to generate a return of $61.86 \%$ over the same three years holding period. In addition, Ritter concluded that there was a high likelihood for firms with high adjusted initial returns to have the worst post IPO performance and this tendency was more evident in the smaller IPO issues than, the larger ones. In the same studies, Ritter also found that there was considerable variation in the underperformance from year to year and across industries, with companies that went public in higher volume years performing the worst. On the other hand, Ritter (1991) concluded that if investors adopt a buy and hold strategy of investing at the end of the first day listing and holding on the portfolio for a three-year period resulted in the investor only having $83 \%$ of the wealth relative to the wealth at the initial period. Ritter (1991) used IPOs and matching firms from the New York Stock Exchanges. This observation is consistent with an IPO market in which investors can sometimes be over-optimistic about the earnings prospects or growth potential of IPO firms. Older IPOs with longer years of operation were found to perform significantly better than younger IPOs.

The long-term underperformance is not just unique to U.S. IPOs. Jelic et al. (2001) examine the long-term performance of Malaysian IPOs from 1980 to 1995. He finds that the 36-month buy-and-hold adjusted return is 
approximately $22.0 \%$ which is significantly positive. Producing similar results to the buy-and-hold method, the cumulative abnormal return was found to be significantly positive as well at 24.8\%. McGuinness (1993) reports a significant market-adjusted return of minus $18.26 \%$ between the close of the first day of trading and the 500 th day of listing of Hong Kong IPOs for the period 1980-1990. In Japan, Cai and Wei (1997) report that five-year holding period returns are 62.1\% for Japanese IPOs and 101.4\% for matched firms during the 1991-1992 period.

Purnanandam and Swaminathan (2004) studied a sample of 2000 relatively large capitalization IPOs between 1980 and 1997. They examined the pricing of IPOs using comparable firms and found that IPOs generally have an offer price $50 \%$ higher than predicted on the basis of industry peers. They also find that the more the IPO is overpriced; the worse will be the long-term performance of the stocks. On the other hand, Sullivan and Unite (2001) report an average raw return of $48.3 \%$ during the 3 years after going public for 104 Philippine IPOs for the period 1987-1997 with the average market-adjusted return is minus $5.4 \%$.

Among the emerging Asian economies, Loughran et al. (1994) report that high average raw returns during the 3 years after going public were earned in Japan (109.6\%), Korea (58.0\%) and Singapore (22.5\%) whilst the market-adjusted returns were significantly lower for Japan (9.0\%) and Korea (2.0\%) and negative for Singapore $(-9.2 \%)$. The results indicate that IPO investment is not beneficial for the average investor in the end.

Based on the above literature the following hypotheses are proposed:

$\mathrm{H}_{1}$ : There is a positive relationship between the size of an IPO offering and the level of initial underpricing.

$\mathrm{H}_{2}$ : There is a positive relationship between market volatility and the level of initial underpricing.

$\mathrm{H}_{3}$ : There is a positive relationship between reciprocal of the IPO subscription price and the level of initial underpricing.

$\mathrm{H}_{4}$ : There is a positive relationship between the reputation of underwriter and the level of initial underpricing.

\section{Research methodology}

\subsection{Sample selection and data}

To investigate the determinants of IPO underpricing and initial market returns in Malaysia, a sample of 313 IPO identities in relation to new listings on the Main Board of Bursa Malaysia from 1 January 1998 to 31 December 2008 were collected. The data for each IPO was extracted from the Bloomberg database and Bursa Malaysia website. The closing price source for Kuala Lumpur Composite Index from 1998 to 2008 was from the Bloomberg and used as a benchmark.

The data was then analyzed using the Statistical Package for Social Sciences (SPSS) version 16.0 program. Prior to input into the program, coding was developed for each variable.

Table 1: Number of IPOs listing in Bursa by year

\begin{tabular}{lrrr}
\hline Year & Total number of IPOs & Number of IPOs included & \% of IPOs included \\
\hline 1998 & 28 & 23 & 82 \\
1999 & 21 & 19 & 90 \\
2000 & 38 & 36 & 95 \\
2001 & 20 & 20 & 100 \\
2002 & 51 & 38 & 75 \\
2003 & 58 & 36 & 62 \\
2004 & 72 & 43 & 60 \\
2005 & 79 & 38 & 48 \\
2006 & 40 & 20 & 50 \\
2007 & 26 & 25 & 96 \\
2008 & 23 & 15 & 65 \\
Total & 456 & 313 & $69 \%$ \\
\hline
\end{tabular}

Table 1 above exhibits the number of IPO listings by year. The initial sample size of IPOs listed on the Bursa between 1998 and 2008 collected is 456 . The sample selection is guided by the availability of data. The selection criteria, specifically the availability of the post 3-year share prices, IPO gross proceeds and identification of underwriters further reduces the sample size to 313 . This constitutes $69 \%$ of all IPOs in the study period. The number of IPOs in the sample varies from year to year depending on the type of analysis and the period considered. The highest number of IPOs was in 2005 with 79 IPOs while the lowest is in 2001 with only 20 IPOs. 
Table 2: Frequency of IPOs and gross proceeds by years

\begin{tabular}{lrrr}
\hline Year & Number of IPOs included & Gross proceeds (RM `000) & \% of total \\
\hline 1998 & 23 & 777741.40 & 3 \\
1999 & 19 & 554635.30 & 2 \\
2000 & 36 & 916640.00 & 4 \\
2001 & 20 & 2829088.90 & 12 \\
2002 & 38 & 2973290.10 & 13 \\
2003 & 36 & 3189860.10 & 14 \\
2004 & 43 & 3158503.20 & 14 \\
2005 & 38 & 3674074.40 & 16 \\
2006 & 20 & 1623365.70 & 7 \\
2007 & 25 & 2450773.70 & 10 \\
2008 & 15 & 1222363.40 & 5 \\
Total & 313 & 23370336.20 & $100 \%$ \\
\hline
\end{tabular}

Table 2 describes the distribution of IPOs the gross proceeds by year. In terms of the percentage of gross proceeds, 2005 seems to be a dominant year in the Malaysian IPO market with the highest proportion of total proceeds (16\%) realized in 2005, followed by 14\% in 2003 and 2004.

Table 3: Division of IPOs and gross proceeds by sectors

\begin{tabular}{lrrr}
\hline Year & Number of IPOs included & Gross proceeds (RM ‘000) & \% of total \\
\hline Construction & 12 & 436075.51 & 2 \\
Consumer products & 68 & 2070926.45 & 9 \\
Finance & 3 & 1146000.00 & 5 \\
Industrial products & 114 & 4730304.27 & 20 \\
Infrastructure & 2 & 1964593.50 & 8 \\
Plantation & 10 & 1304654.53 & 6 \\
Properties & 12 & 1243410.56 & 5 \\
REITs & 11 & 2234319.21 & 10 \\
Technology & 13 & 632545.88 & 3 \\
Trading service & 68 & 7607506.30 & 33 \\
Total & 313 & 23370336.20 & $100 \%$ \\
\hline
\end{tabular}

Table 3 shows the division of IPOs among sectors and the distribution of proceeds by sectors. Of the 313 IPOs, 114 IPOs are under industrial products category, 68 IPOs from both consumer products and trading service and 13 IPOs under Technology. Meanwhile, both Properties and Construction sectors have 12 IPOs each, REITs record 11 IPOs, Plantation 10 IPOs, and Finance 3 IPOs while the remaining 2 IPOs were from Infrastructure services.

The gross proceeds raised by the sample IPOs vary substantially. In terms of gross proceeds, the Trading Service sector topped the list with the highest proceeds at RM7.6billion, followed by Industrial Products at RM4.7billion. The least amount of gross proceeds raised is from Construction sector at RM436million.

\subsection{Empirical methodology (short-run underpricing)}

For each IP0, two short-run measures of performance are used which are widely practiced in international empirical studies: the raw returns and the excess or adjusted returns. In line with research methods employed by Ritter (1991) and Jelic et al. (2001), the raw returns for each stock is defined as relative price change from offer price to closing price at the end of first trading day as follows:

Intial return $=\frac{P_{i}-P_{0}}{P_{0}} * 100$

Where Pi = closing price on the first day of the firm. Po is the IPO offer price. Exploiting the same method by using the IPO price as a base, the raw returns for $2^{\text {nd }}, 3^{\text {rd }}, 4^{\text {th }}, 5^{\text {th }}, 10^{\text {th }}, 20^{\text {th }}$ day are calculated as well.

As suggested by Loughran and Ritter (2000), adjusting the raw returns with an appropriate benchmark is important because it often determines the presence of positive or negative abnormal returns. Hence, even though raw returns are measured but they may not be adequate for measuring both short and long-run performances of an IPO. As well, an appropriate benchmark is used when making comparisons with respect to risks and returns as suggested by Drobetz, Kammermam, Walchli (2002). 
Selection of an appropriate benchmark is important when calculating the abnormal returns and comparing the results to that benchmark because quantitative measurements for the short and long-run performances of IPOs can be susceptible to the method and benchmark employed.

According to Ewing and Ozfidan (2003), the National 100 Index of the Istanbul Stock Exchange is a more established benchmark, and so it is a less risky yardstick compared to a portfolio comprised of IPO stocks. Besides, the use of market returns to calibrate nominal returns could result in a situation where there are more positive excess returns than using a riskier benchmark. Meanwhile, Jelit et al. (2001) used the Kuala Lumpur Composite Index (KLCI) as the benchmark in their studies on the Malaysian IPO market that clearly represents the sample of IPOs being analyzed.

Following the same formula used to calculate the raw return, the same interval is also used to estimate the raw returns for the KLCI of the Bursa.

Intial return $=\frac{K L C I_{i}-K L C I_{0}}{K L C I_{0}} * 100$

Where $\mathrm{KLCI}_{\mathrm{i}}=$ Closing value of the $\mathrm{KLCI}$ on the first day. $\mathrm{KLCI}_{0}$ is the value of the $\mathrm{KLCI}$ on the IPO listing date.

The estimation of excess return combines the returns of the shares with the fluctuations of the market. In order to evaluate whether a firm's IPO over or underperforms the market, the difference between the raw return of the IPO and the return of the KLCI is calculated for the same time interval. The initial market-adjusted return for each stock is defined as the initial raw return less the corresponding market return on initial day. This kind of evaluation will reveal whether the IPO over or underperforms the market.

Market - adjusted return $=\frac{P_{i}-P_{0}}{P_{0}}-\frac{K L C I_{i}-K L C I_{0}}{K L C I_{0}} * 100$

Where $i, O$ are defined as above, $\mathrm{P}$ is the closing price of the stock and KLCI is the value of Bursa Index.

\subsection{Empirical methodology (long-run underpricing)}

In order to gain further understanding of IPO underpricing, share returns up to three years subsequent to listing are analyzed. "Fad" or "speculative bubble" explanations of initial underpricing suggest a link between initial returns and post-listing performance. While IPO underpricing is widely documented, there is relatively little evidence of long-run performance.

For this purpose, the closing share price of the IPO on the day of listing was obtained together with the closing prices for the 36 months following the day of listing. Long-term performance of IPOs is examined by analyzing their holding period return over a period and comparing them with the market return. Hence, aftermarket returns are calculated as holding period return, i.e., buying the IPO shares on the first trading day and holding them for a pre-determined period. The predetermined periods are 6, 9, 12, 18, 24 and 36 months. The average buy and hold returns $\left(\mathrm{RET}_{\mathrm{i}, \mathrm{t}}\right)$ is calculated as follows:

$$
R E T_{i, t}=\prod_{i=1}^{n}\left(1+r_{i, t}\right)-1
$$

where $\mathrm{n}$ is the number of months comprising the period and $\mathrm{r}_{\mathrm{i}, \mathrm{t}}$ is the rate of return of the stock $i$ at time $t$ calculated as the percentage change of the price of stock $i$ from first day price of month $t$ (Price $\mathrm{i}_{i, 0}$ ) to the last day price of month $t$ (Price $i, t)$.

$$
r_{i, t}=\frac{\text { Price }_{i, t}}{\text { Price }_{i, 0}}-1
$$

\subsection{The explanatory variables and the model}

There are several hypotheses regarding the possible explanations for IPOs performances. Generally, the literature on underpricing relates to underpricing phenomena to ex-ante uncertainty as in Rock (1986); Beatty and Ritter, (1986). The study is further expanded to determine possible explanations for underpricing phenomenon in the Malaysian context. The empirical analysis is extended to examine whether the variables capable of explaining the initial returns of IPOs in other developed markets can explain the initial return in Malaysia. 
In line with these studies, a positive relationship between the level of underpricing and the level of ex-ante uncertainty of a new issue is expected. Since it is not possible to measure ex-ante uncertainty directly, a number of variables are used as proxies. There are two variables used as proxies for ex-ante uncertainty in this study. They are IPO size measured by the gross proceeds from going public and market volatility.

The ordinary least squares regression is used to determine the factors affecting IPO initial returns in Malaysia. The explanatory power of these variables on initial underpricing listed is explored by estimating using the following equation. The explanatory variables used in the model are selected based on previous empirical research.

$$
\operatorname{RETURN}=\beta_{0}+\beta_{1}(\text { Size })+\beta_{2}(\mathrm{MV})+\beta_{3}(\text { RECIPO })+\beta_{4}(\text { UW Status })+\epsilon i
$$

Where:

Size $\quad=$ Gross proceeds raised from IPO

MV = Market Volatility of KLCI

RECIPO = Reciprocal of the IPO subscription price

UW Status = Underwriter Status

Gi

$$
=\text { An error term }
$$

To test $\mathrm{H}_{4}$ for Malaysian IPOs, a dummy variable is employed. This variable takes the value of 1 if the underwriter is reputable and zero if the underwriter is non-reputable. Studies have used several proxies to measure the reputation of underwriters. The measure used here assumes that and Commerce International Merchant Bankers (CIMB) and Arab Malaysian Merchant Bankers (AMMB) are the prestigious underwriters. These two firms are designated as prestigious underwriters in this study based on their IPO market share. In an article published by Asiamoney (November 1999) titled "Humbling of Daim Zainuddin" by Matthew MontaguPullock, the author states: “CIMB is Malaysia's number one or number two merchant bank, together with AMMB.

\section{Empirical findings and results}

\subsection{Short run performance}

Having defined the variables, this analysis is then carried out in two stages. In the first stage, the relationship between the returns is analyzed by comparing mean returns and by univariate regression analysis. In the second stage, the determinants of returns are examined by cross sectional analysis and multivariate regression analysis.

Table 4: Return analysis of IPOs

\begin{tabular}{lrrrrr}
\hline Return & Number of observations & Minimum \% & Maximum \% & Mean \% & Std. Deviation \\
\hline Initial market-adj. & & & & & \\
returns & 313 & -18.0 & 82.0 & $9.4^{*}$ & .781 \\
D1 & 313 & -30.0 & 118.0 & $13.4^{*}$ & 1.122 \\
D2 & 313 & -33.0 & 121.0 & $13.7^{*}$ & 1.171 \\
D3 & 313 & -50.0 & 135.0 & $13.9^{*}$ & 1.291 \\
D4 & 313 & -53.0 & 127.0 & $13.9^{*}$ & 1.274 \\
D5 & 313 & -60.0 & 142.0 & $14.0^{*}$ & 1.332 \\
D10 & 313 & -62.0 & 146.0 & $19.0^{*}$ & 1.351 \\
D20 & 313 & -65.0 & 133.0 & $19.0^{*}$ & 1.21 \\
\hline
\end{tabular}

Table 4 below shows the descriptive statistics for the initial market adjusted returns and after-market returns for Day 1, 2, 3, 4, 5, 10 and 20. The first day adjusted return is $9.4 \%$ for all companies. The results show that, on average, an initial underpricing of $13.4 \%$ at the end of the first day, $13.7 \%$ for the second day, $13.9 \%$ for both third and fourth day, $14 \%$ for the fifth day and $19 \%$ for the $10^{\text {th }}$ and $20^{\text {th }}$ day. These returns are statistically significant at $5 \%$ level.

These results demonstrate that IPOs in Malaysia, like other international IPOs, experience a statistically significant underpricing both on the initial day and in the immediate after-market periods. These results are in line with those of other international IPO studies.

Table 5 exhibits the univariate regression results of market adjusted returns for 12-month, 24-month and 36month periods. The estimated coefficients demonstrate the relationship between long-term returns, namely RET $_{12}, \mathrm{RET}_{24}$ and RET 36 and short-term returns of IPOs tend to be negative. It is noteworthy that marketadjusted returns for 36-month, $\mathrm{RET}_{36}$ is inversely related to initial returns and the negative coefficient of -0.195 is statistically significant at the $5 \%$ level. The results confirm that long-term performance is negatively 
associated with short-term returns that indicate that the market corrects the overvaluation or underpricing of IPOs once the realization of the high initial returns. Moreover, this result provides supporting evidence for the "fads" hypothesis. That is, in the long-run, the market acts to correct the IPO overvaluation experienced in the short run. Moreover, the $\mathrm{R}^{2}$ values are almost equal to zero for the long-term return regression equations showing the diminishing power of short-term returns in explaining long-term returns expected from the new issues.

Table 5: Univariate regression results

\begin{tabular}{|c|c|c|c|c|c|c|c|}
\hline $\begin{array}{l}\text { Dependent } \\
\text { variable }\end{array}$ & $\begin{array}{l}\text { Independent } \\
\text { variable }\end{array}$ & $\begin{array}{l}\text { Estimated } \\
\text { coefficient }\end{array}$ & $\mathrm{t}$ & $\begin{array}{r}\text { Standard } \\
\text { error }\end{array}$ & $\mathrm{R}^{2}$ & $\mathrm{~F}$ & D-W \\
\hline $\mathrm{RET}_{12}$ & $\begin{array}{l}\text { Initial market- } \\
\text { adj returns }\end{array}$ & -0.022 & -0.394 & 0.0781 & 0.001 & 0.155 & 2.024 \\
\hline $\mathrm{RET}_{24}$ & $\begin{array}{l}\text { Initial market- } \\
\text { adj returns }\end{array}$ & -0.101 & -1.759 & 0.0788 & 0.007 & 3.094 & 2.050 \\
\hline $\mathrm{RET}_{36}$ & $\begin{array}{l}\text { Initial market- } \\
\text { adj returns }\end{array}$ & $-0.195^{* *}$ & -3.32 & 0.0759 & 0.038 & 11.02 & 1.947 \\
\hline
\end{tabular}

${ }^{* *}$ Correlation is significant at the $1 \%$ level (2-tailed)

Durbin-Watson test statistics are used to measure for correlations between errors. Specifically, it tests whether the residuals are correlated. The score can vary between 0 and 4 with a value of 2 meaning that the residuals are uncorrelated. As a rule of thumb, values less than 1 and greater than 3 are cause for concern. Based on Table 5, the Durbin-Watson test statistics results are close to 2, suggesting that the residuals are uncorrelated. In the second stage, the relationship between the determinants of IPO returns and returns is investigated.

The Pearson correlation matrix was used to determine the relationship for all the continuous variables used in the IPO underpricing model. Table 6 exhibits the Pearson correlation coefficient (r) among all the variables used in the IPO underpricing model.

Table 6: Pearson correlation matrix for continuous variables

\begin{tabular}{lrrrrrrr}
\hline & Mean & $\begin{array}{r}\text { Std. } \\
\text { Deviation }\end{array}$ & Return & IPO size & $\begin{array}{r}\text { Market } \\
\text { volatility }\end{array}$ & $\begin{array}{r}\text { Underwriter } \\
\text { status }\end{array}$ & $\begin{array}{r}\text { Reciprocal } \\
\text { of IPO price }\end{array}$ \\
\hline Initial market-adj & & & & & & & \\
Returns & 9.36 & 0.08 & 1.000 & $0.729^{* *}$ & $0.649^{* *}$ & $0.13^{*}$ & -0.099 \\
IPO size & 74.67 & 20.79 & $0.729^{* *}$ & 1.000 & $0.675^{* *}$ & 0.091 & $-0.117^{*}$ \\
Market volatility & 42.47 & 15.23 & $0.649^{* *}$ & $0.675^{* *}$ & 1.000 & 0.124 & $-0.171^{* *}$ \\
Underwriter status & 0.46 & 0.50 & $0.13^{*}$ & 0.091 & 0.124 & 1.000 & -0.039 \\
Reciprocal of IPO price & 1.35 & 1.67 & -0.099 & $-0.117^{*}$ & $-0.171^{* *}$ & -0.039 & 1.000 \\
\hline
\end{tabular}

*Correlation is significant at the $1 \%$ level (2-tailed)

**Correlation is significant at the $5 \%$ (2-tailed)

The Pearson correlation coefficient indicates the degree to which the variables are related. It can range from 1.00 (perfect negative correlation) to 1.00 (perfect positive correlation). According to Cohen (1988), a correlation coefficient between 0.10 and 0.29 indicate a small correlation, a correlation coefficient between 0.30 and 0.49 indicate a medium relationship and a coefficient between 0.50 and 1.0 indicate a significant coefficient.

It is noted that although some of the independent variables are correlated none of the coefficients is too high. To check for the possibility of multicollinearity problems, variance inflation factors (VIF) are determined. It is noted that none of the variance inflation factors (VIF) for the explanatory variables are greater than four, suggesting that multicollinearity is not a cause for concern in the IPO underpricing model.

Table 6 also reveals that IPO size, market volatility, and underwriter status are positively correlated to initial return. The correlation analysis results showed that both IPO size and market volatility have a significant positive relationship with the initial return as the correlation coefficients $(r)$ are large $(r>0.50)$. The strongest relationship is seen between initial return and IPO size at $r=0.729$ and statistically significant at $1 \%$ level. Market volatility showed $r=0.649$ and statistically significant at $1 \%$ level while underwriter status showed a weaker positive relationship with the initial return at $r=0.13$ and it is statistically significant at $5 \%$ level. It is worth noting that reciprocal of IPO price is inversely related to with initial return. The weakest correlation $(\mathrm{r}=$ 0.099 ) is observed between return and reciprocal of IPO price albeit insignificant at the conventional level. 


\section{Discussion}

The regression results are reported in Table 7 concerning the explanatory variables (IPO size, market volatility, underwriter status and reciprocal of IPO price) influencing the level of initial underpricing in Malaysia during the period 1998 to 2008 .

Table 7: Results of multiple regression analysis

\begin{tabular}{lrr}
\hline Variables & Coefficient (1) & Coefficient (2) \\
\hline Constant & & $0.534^{*}$ \\
IPO size & $0.286^{*}$ & 0.291 \\
Market volatility & 0.046 & - \\
Underwriter status & 0.014 & 0.014 \\
Reciprocal of IPO price & & \\
Dummy underwriter status & & 313 \\
(reputable=1) & & 313 \\
& $1.016-1.878$ & $1.016-1.878$ \\
Observations & 0.580 & 0.577 \\
VIF range & 0.574 & 0.573 \\
R $^{2}$ & & \\
Adjusted R & & \\
\hline
\end{tabular}

* Indicates significant at the 5\% (2-tailed)

The signs of the explanatory variables are in line with the theory, and the fit of line 0.574 is satisfactory since this is a cross sectional data. In other words, the four explanatory variables taken together explain about $57.4 \%$ of the variation in the IPO initial underpricing. The regression estimates as reported in Table 10 show that there is a positive correlation between initial underpricing and all the variables, namely IPO size, market volatility, underwriter status and reciprocal of IPO price. The IPO size was found to be the most significant variable influencing IPO initial underpricing with a coefficient of 0.534 and is statistically significant at $5 \%$ level. The least important variable influencing IPO underpricing is reciprocal of IPO price with a coefficient of 0.014 , and it is not statistically significant at any meaningful level.

$\mathrm{H}_{1}$ : There is a positive relationship between the size of an IPO offering and the level of initial underpricing. The multiple regression results in Table 7 show that IPO size has the expected positive sign. The coefficient is 0.534 and is statistically significant at 5\% level. This shows that the size of the IPO offering has a significant positive relationship on the level of initial underpricing. This result is consistent with the findings of Allen and Faulhaber (1989) who suggest that IPOs which are larger in size tend to be underpriced by a larger margin.

\section{$\mathrm{H}_{2}$ : There is a positive relationship between market volatility and the level of initial underpricing.}

Consistent with expectation, the market volatility has the expected positive sign. The coefficient of this variable is 0.286 is statistically significant at $5 \%$ level. This indicates market volatility is one of the main determinants of underpricing. This finding is supportive of the results by Menyah and Paudyal (1996) where they observed issues tend to set the offer price below the true "intrinsic" price at a time of high market volatility.

\section{$\mathrm{H}_{3}$ : There is a positive relationship between reciprocal of the IPO subscription price and the level of initial} underpricing.

Multiple regression results as exhibited in Table 7 demonstrate that the reciprocal of IPO price has a positive relationship on the level of IPO underpricing. The coefficient for this variable is 0.046 , and it is not statistically significant at any meaningful level. This signifies that the magnitude of underpricing is higher for low-priced IPOs which is consistent with the empirical findings by Chalk and Peavy (1987). This is reasonable as the higher the subscription price, the harder it will be for average investors to afford the stocks as the price can be too high.

$\mathrm{H}_{4}$ : There is a positive relationship between the reputation of underwriter and the level of initial underpricing. The results also reveal that reputation of underwriter reputation has a positive relationship with the magnitude of initial underpricing. The coefficient for this predictor is 0.014 , and it is not statistically significant at $5 \%$ level. This proposition implies that IPOs underwritten by reputable underwriters may signal that they are good and safe investments, in which case investors tend to pay a higher price in the market, pushing the share price upwards, and resulting in initial excess returns. The results are consistent with the findings by Jelic et al. (2001) which reported that underwriters with a better reputation tend to, on average, increase initial underpricing. To examine the implication of the underwriters' status on underpricing, a dummy variable is created to indicate the reputation of the underwriters $(0=$ non-reputable underwriter, $1=$ reputable underwriter $)$. When the regression is re-run using dummy variables to indicate whether the status of the underwriter in an IPO 
influences IPO underpricing, both the results (coefficient 1 and 2) are qualitatively similar. The adjusted $\mathrm{R}^{2}$ remains almost unchanged at 0.57 which indicates the status of the underwriter is not a significant variable. In other words, there is no significant difference in these 2 models and provide evidence against information advantage of reputable underwriters.

In all the regressions undertaken, the regressions coefficients of IPO size and market volatility are predominantly positive. The coefficients for IPO size and market volatility are statistically significant at $5 \%$ level, indicating their strong predictive power in influencing the magnitude of IPO initial underpricing. Hence, in brief, only two variables (IPO size and market volatility) out of the four variables outlined in the model have a significant and positive impact on the magnitude of initial underpricing of IPOs in Malaysia. Overall, the analysis suggests that IPO size, market volatility, underwriter status and reciprocal of IPO price can explain over $57 \%$ of the variation in the level of underpricing.

\section{$5.1 \quad$ Long-run performance}

To gain further understanding of IPO underpricing, IPO returns in the first three years subsequent to listing are calculated. The main emphasis of this section is to investigate the long-term return performance of IPO. The analysis of longer-term returns will be used to see if the large initial returns are really evidence of underpricing or whether they are signs of investor irrationality. While IPO underpricing is widely documented, there is relatively little evidence of long-run performance.

Table 8: Long-run analysis of IPOs

\begin{tabular}{lrrrrr}
\hline Return & Number of observations & Minimum \% & Maximum \% & Mean \% & Std. Deviation \\
\hline RET $_{6}$ & 313 & -37.0 & 51.0 & 1.0 & 0.085 \\
RET $_{9}$ & 313 & -37.0 & 54.0 & 1.0 & 0.086 \\
RET $_{12}$ & 313 & -40.0 & 47.0 & -2.0 & 0.087 \\
RET $_{18}$ & 313 & -48.0 & 42.0 & -5.0 & 0.087 \\
RET $_{24}$ & 313 & -66.0 & 38.0 & $-8.0^{*}$ & 0.086 \\
RET $_{30}$ & 313 & -90.0 & 32.0 & $-10.0^{*}$ & 0.103 \\
RET$_{36}$ & 313 & -93.0 & 23.0 & $-15.0^{*}$ & 0.110 \\
\hline
\end{tabular}

* Indicates significant at the $5 \%$

Table 8 reports long-run returns for IPOs up to 36 months subsequent to listing calculated based on a buy-andhold strategy where stock purchased at the IPO offer price from the first day of listing and holding the stock for up to 36 months.

The results in Table 8 reveal that IPOs on average performed quite poorly over the longer run. The average buyand-hold return has a maximum return of $54 \%$ and the minimum return of $-93 \%$. The mean returns for 6 -month and 9-month are both $1 \%$ with a standard deviation of 0.085 and 0.086 respectively. The notable point is that the mean returns turned into negative from 12-month onwards, indicating that IPOs underperformed the market after one year from the listing date. The average buy-and-hold returns for 24,30 and 36-month are -8\%, $-10 \%$ and $-15 \%$ respectively, and statistically significant at $5 \%$ level. These results suggest the same general findings as in Ritter (1991) which report that on average, IPOs performed poorly in the end.

Finally, in order to examine the four determinants that may have significant influence on the long-term returns of IPOs, the long-term returns are regressed against a set of explanatory variables using the following equation:

$\mathrm{LR}_{i}=\beta_{0}+\beta_{1}($ Size $)+\beta_{2}(\mathrm{MV})+\beta_{3}(\mathrm{RECIPO})+\beta_{4}(\mathrm{UW}$ Status $)+\mathrm{Gi}$

where:

LR $\quad=$ Long-term return of firm $i$ for year 1,2 and 3

Size $\quad=$ Gross proceeds raised from IPO

MV $\quad=$ Market Volatility of KLCI

RECIPO $\quad=$ Reciprocal of the IPO subscription price

UW Status = Underwriter Status

Gi

$=$ An error term

Table 9 below presents the estimation results of the multiple regression analysis. Unlike the initial underpricing, the 1,2 and 3-year returns are inversely related to the IPO size. However, this relationship does not remain stable as it has no significance on year 1 return but is statistically significant at $5 \%$ level in Year 2 and Year 3 returns. The market volatility variable is positively related to longer post-listing periods but has no statistically 
significant association with the long-term returns. Similarly, the reciprocal of IPO price is also positively related to long-term returns, and their coefficients are not significant at any meaningful level. The underwriter status has negative coefficients in the long-run estimated regression equations of long-term returns, but none is found to be statistically significant. It is also noteworthy that the explanatory power of this model increases with the length of the period as the adjusted $\mathrm{R}^{2}$ increases progressively from $0.3 \%$ for Year 1 model, 3.2\% for Year 2 model and 19.8\% for Year 3 model. This signifies that these variables are more applicable to Year 3 model compared to Year 1 and Year 2 models. These long-run market adjusted returns models are not expected to have high predictive power, as this would imply that the long-run share market performance could be predicted at the IPO date.

Table 9: Multivariate regression analysis

\begin{tabular}{|c|c|c|c|}
\hline Variables & 1-year returns & 2-year returns & 3-year returns \\
\hline Constant & -0.053 & -0.095 & -0.145 \\
\hline IPO size & -0.05 & $-0.251^{*}$ & $-0.463^{*}$ \\
\hline Market volatility & 0.156 & 0.096 & 0.024 \\
\hline Underwriter status & -0.023 & -0.039 & -0.016 \\
\hline Reciprocal of IPO price & 0.036 & -0.044 & 0.05 \\
\hline Observations & 313 & 304 & 280 \\
\hline VIF range & $1.016-1.878$ & $1.016-1.878$ & $1.016-1.878$ \\
\hline $\mathrm{R}^{2}$ & 0.016 & 0.045 & 0.209 \\
\hline Adjusted R ${ }^{2}$ & 0.003 & 0.032 & 0.198 \\
\hline
\end{tabular}

* Indicates significant at the 5\% (2-tailed)

\section{Conclusions}

The underpricing of IPOs is recognized as one of the anomalies that have been a rich field for investigation in the financial community. This paper aims to provide additional evidence on the IPOs by examining the Malaysian Stock Exchange, Bursa Malaysia, which is one of the growing emerging markets in Asia. This paper investigates the underpricing phenomenon in Malaysian IPOs, by observing the behavior of market-adjusted initial returns, the short-run and long-run performance of these firms.

Cross sectional data of 313 companies listed and traded in the Bursa during the period 1998 to 2008 provide empirical evidence of underpricing of IPOs. The first day adjusted return is $9.4 \%$. Regarding the magnitude of underpricing, the result show, on average, an initial underpricing of $13.4 \%$ at the end of the first day, $13.7 \%$ on the second day, $13.9 \%$ on the $3^{\text {rd }}$ and $4^{\text {th }}$ day, $14 \%$ for the $5^{\text {th }}$ day and $19 \%$ for the tenth and twentieth day. These results are highly significant and are in line with the results of other international studies on IPOs.

In addition, this study aims to provide some practical insights into the short-run and long-run IPO performance in Malaysia. This study will be of great interest to investors, analysts, stock brokers, fund managers, and academicians. It will enlighten our understanding of aftermarket performance of the new issues and would be of great interest to eager investors. Specifically, an attempt is made to address the following questions: How would IPOs perform when compared with the general market over a longer period? Would an investor gain more by holding such investment after its listing? Should we sell our stocks immediately after the listing? Would the high initial returns significantly above average after market or is the underpricing of new issues detrimental to the long-term well-being of the companies?

It is hoped that the results of this paper add to the growing number of international evidence and shed additional light on the behavior of IPOs in the long-run with data from the Malaysian market. In computing, longrun performance, this study incorporates returns up to three years after listing to facilitate comparison with most of studies done previously. The long-run performance of Malaysian IPOs is measured based on the methodology proposed by Ritter (1991). One of the benefits of studying the long-run performance of IPOs is that it allows the investors who missed out or who were rejected on the initial period due to over-subscription to gain further insights on the long-run performance of IPOs.

\section{References}

Aggarwal, R. and P. Rivoli (1990),'Fads In The Initial Public Offerings Market?, Financial Management, Vol.19, No.4, pp.45-57. 
Allen, F. and G Faulhaber (1989), 'Signaling by Underpricing in the IPO Market', Journal of Financial Economics, Vol. 23, pp.303-323

Baron, D (1982), 'A Model of Demand for Investment Banking Advising and Distribution Services for New Issues', Journal of Finance, Vol.37 pp.955-976

Beatty, R., and J. Ritter (1986), 'Investment Banking, Reputation, and the Underpricing of Initial Public Offerings, Journal of Financial Economics, Vol.15, pp.213-232

Beatty, R. and I. Welch (1996), 'Issuer expenses and legal liability in initial public offerings', Journal of Law and Economics, Vol. 34, pp.545-602

Beckman, J., Garner, J., Marshall, B., Okamura, H., (2001), 'The influence of underwriter reputation, keiretsu affiliation and financial health on the underpricing of Japanese IPOs', Pacific Basin Finance Journal 9, pp.513-534

Benveniste, L. M. and Paul A. Spindt (1989), 'How investment bankers determine the offer price and allocation of new issues', Journal of Financial Economics Vol.24, pp.343-361

Benveniste, James R. and Richard L. Smith (1986) 'Capital Raising, underwriting and the certification hypothesis', Journal of Financial Economics, Vol.15, pp. 261-281

Brennan, M. and Franks, J. (1997), 'Underpricing, ownership and control in initial public offerings of equity securities in the UK', Journal of Financial Economics, Vol. 45, pp 391-413

Carter, R., Dark, F., Sing, A., (1998) 'Underwriter reputation, initial returns and the long run performance of IPO stocks', Journal of Finance, Vol.53, pp. 285-311

Carter, R., and Manaster, S. (1990), 'Initial Public Offering and Underwriter reputation', Journal of Finance, Vol.40, pp.1045-1067

Chemmanur, T.J. (1993), 'The pricing of initial public offerings: a dynamic model with information production', Journal of Finance, Vol.48, pp 285-304

Demers, E., Lewellen, K., (2003), 'The marketing role of IPOs: evidence from Internet stocks', Journal of Financial Economics Vol.68, pp. 439-484

Ibbotson, R.G., Jaffe, J.F.,(1975), ' Hot issue markets', Journal of Finance Vol.30., pp1027-1042

Jelic, R., Saadouni, B., and Briston, R. (2001), 'Performance of Malaysian IPOs: underwriters reputation and management earnings forecasts', Pacific-Basin Finance Journal, Vol.9, pp.457-486

Jensen, M.C. (1986), 'Agency Costs of free cash flow, corporate finance and takeovers', American Economic Review, Vol.76., pp.323-339

Kang, J.-K, Kim, Y.-C., Stultz R. (1999), 'The under-auction hypothesis and the new issue puzzle: evidence from Japan', Review of Financial Studies, Vol12, pp.519-534

Keloharju, Matti (1993), 'The winner's curse, legal liability, and the long-run price performance of initial public offerings in Finland', Journal of Financial Economics, Vol.34, pp.251-277

Koh, Francis and Terry Walter (1989), 'A direct test of Rock's model of the pricing of unseasoned issues', Journal of Financial Economics, Vol.23, pp.251-272

Levis, M. (1993), 'The Long-run performance of Initial Public Offerings: The UK Experience 1980-1988', Financial Management, Vol.22, pp.28-41

Logue, D., (1973), 'On the pricing of unseasoned equity issues: 1965-1969, Journal of Financial and Quantitative Analysis', January, pp.91-103

Loughran, T. Ritter, J.R., (1995), 'The new issues puzzle', Journal of Finance Vol.50, pp.23-51

Loughran, T., Ritter, J., Rydqvist, K., (1994 updated 2000,) 'Initial public offerings: International insights', PacificBasin Finance Journal 2, 165-199.

McGuiness, P., (1993b), 'The post-listing return performance of seasoned issues of common stock in Hong Kong', Journal of Business Finance and Accounting, Vol.20, pp.167-194

McLAughlin, R., Vasudevan, G., Saffiedine, A., (1996), 'The operating performance of seasoned equity issuers: free cash flow and post-issue performance', Financial Management, Vol.25, pp.41-53

Miller, R. E., \& Reilly, F. K., (1987), 'An Examination of Mispricing, Returns, and Uncertainty for Initial Public Offerings. Financial Management, Vol.16, pp.33-38.

Purnanandam, A.K., Swaminathan, B. (2004), 'Are IPOs really underpriced?' The Review of Financial Studies, Vol.17, pp.811-848

Ritter, J.R., (1984), 'The hot issue market of 1980', Journal of Business, Vol.57, pp215-240

Ritter, J.R., (1991), 'The long-run performance of initial public offerings', Journal of Finance, Vol.46, pp.3-28

Ritter, J.R., (1987), 'The costs of going public', Journal of Financial Economics, Vol.19, pp.269-281

Ritter, J.R., (1988), 'Initial Public Offerings' Contemporary Finance Digest, pp5-30

Ritter, J.R., (2003), 'Investment Banking and Securities issuance', Chapter 5.

Rock, K., (1986), 'Why new issues are under-priced', Journal of Financial Economics Vol.15, pp187-212

Shiller, R.J., (1990), 'Speculative prices and popular models', Journal of Economic Perspectives' Vol4. Pp.55-65

Sullivan, M.J., Unite, A.A., (2001), The influence of group affiliation and the under-pricing process on emerging market IPOs: the case of the Philippines. Pacific-Basin Finance Journal Vol9., pp.487-512

Welch, I., (1992), 'Sequential sales, learning cascades. Journal of Finance, Vol.47, pp695-732. 